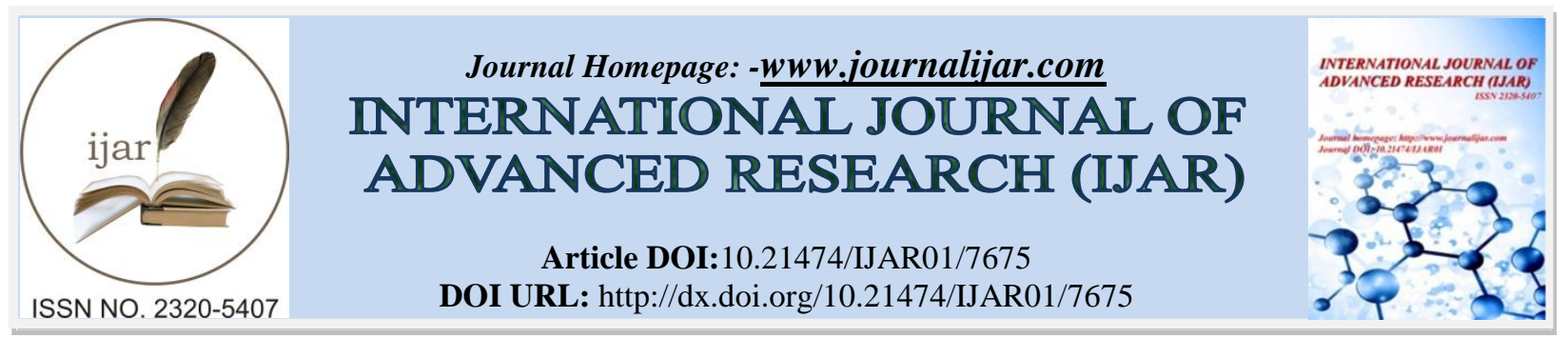

RESEARCH ARTICLE

\title{
EVALUATION OF HEPATOPROTECTIVE ACTIVITY OF CARICA PAPAYA AND FICUS BENGALENSIS LATEX ON THIOACETAMIDE INDUCED HEPATOTOXICITY IN RATS.
}

Yogendra kumar ${ }^{1}$, Girendra Gautam ${ }^{2}$ and Pushpesh Kumar Mishra ${ }^{3}$.

1. Research Scholar, Faculty of Pharmacy, Bhagwant University, Sikar Road, Ajmer, Rajasthan, India.

2. Faculty of Pharmacy, Bhagwant University, Sikar Road, Ajmer, Rajasthan, India

3. Department of Chemistry, Faculty of Pharmacy, Naraina Group of Institutions, Kanpur, U.P., India

\section{Manuscript Info}

\section{Manuscript History}

Received: 06 July 2018

Final Accepted: 08 August 2018

Published: September 2018

Keywords:-

Thioacetamide, Carica Papaya, Ficus Bengalensis, Hepatoprotective, Silymarin.

\section{Abstract}

Study was designed to evaluate the hepatoprotective activity of Carica Papaya Latex at the dose $400 \mathrm{mg} / \mathrm{k} . \mathrm{g}$. and Ficus Bengalensis Latex at the dose $300 \mathrm{mg} / \mathrm{k}$.g. per oral induced by thioacetamide at the dose $100 \mathrm{mg} / \mathrm{k} . \mathrm{g}$. S.C..Hepatoprotective activity was observed by using biochemical parameters such as Serum-Glutamate Pyruvate Transaminase and Serum-Glutamate Oxalate Transaminase (SGPT and SGOT), total protein, Bilirubin, Alkaline Phosphate (ALP).

Carica Papaya and Ficus Bengalensis Latex produced significant hepatoprotective effect by decreasing the activity of serum enzyme like SGPT, SGOT, Bilirubin, ALP, and elevated total protein level. Both plants latex were found completely prevented the toxic effect of thioacetamide on above serum parameters.

Copy Right, IJAR, 2018,. All rights reserved.

\section{Introduction:-}

Liver is the largest organ in the body weighing 1400-1600 gm in the males and 1200-1400gm in females. Liver performs various multifold functions are metabolism of proteins, lipid, carbohydrate and excretion of bile, detoxification of toxic substance such as alcohol and drugs [1]. It has important role in the maintenance and regulating homeostasis of the body. It is also involve with biochemical pathway to fight against to disease, growth, reproduction and nutrition supply [2].

The morbidity and mortality of different types of liver disease have rises around the world[3]. Alcohol, prescribed drug and over the counter drug which can eventually lead to various liver ailments like alcoholic liver disease, cirrhosis, hepatitis[4],[5]. The untreated liver disease and long term uses of medication sometime cause toxic effect and finally may lead to death[6]. In recent times various plants have been used for prevention of liver disease [7]. Medicinal plants are used in the natural medicines such as Unani medicine and Indian Ayurveda [8].

Ficus Bengalensis plant is commonly known as Banyan tree in Ayurveda[9]. Ficus Bengalensis belong to family Moraceae. Leaves contain crude proteins $9.63 \%$, Cao-2.53\% and phosphorus 0.4\% [10],[11]. The extracts of Ficus Bengalensis have been reported to decrease insulinase activity from liver and kidney [12].

Various extracts of Ficus Bengalensis were reported anti-allergic and anti-stress potential in asthma by milk induced leucocytosis and milk induced eosinophilia[13]. A milky juice (Latex) of stem bark of Ficus Bengalensis is used for treatment of rheumatism.

Corresponding Author:-Yogendra Kumar.

Address:-Research Scholar, Faculty of Pharmacy, Bhagwant University, Sikar Road, Ajmer, Rajasthan, India. 
Ficus Bengalensis bark aqueous extracts reported inflammation and swelling in pancreatic tissue and restored the levels of serum electrolytes [13, 14, and 15].

Carica Papaya Linn plant belongs to family Caricaceae is a tropical tree. It is native to the tropics of an Americas but now widely cultivated in other tropical regions of the world. Plant is available throughout the year[16]. Carica Papaya is fast growing plant, it measure 7-8m with copious latex and trunk about $20 \mathrm{~cm}$ in diameter [17].

Phytochemical studies have been shown Carica Papaya contains different chemical constituents like flavonoids, nicotins, tannins, terpinenes, alkaloids and it also contain enzyme like Chymopapain and papain[18][19].

Aqueous extracts of unripe Carica papaya have been reported antisickling and reversal of sickling properties [20]. Latex, juice and fruit of Carica Papaya have digestive properties and it is reported in used habitual constipation and chronic diarrhea [21]. Carica Papaya Latex reported wound healing properties [22].

\section{Material and Methods:-}

Plant materials

Carica Papaya and Ficus Bengalensis were collected from Mathura, Uttar Pradesh. The authentication and identification was done by (Prof.) Dr. D.K. Singh, Department of Botany, KR (PG) College, Mathura, Uttar Pradesh.

\section{Carica Papaya Latex Collection}

Latex was collected locally in early morning 7:00 to 8:00 am, as the flow of latex is low during the day. Collection was done by making 1-2 mm deep vertical incisions on the skin of unripe fruit, but mature fruit. The latex was then dried at room temperature till it became crumbly and non-sticky. The dried latex was triturated using a mortar and pestle.. It was stored at $4-8{ }^{\circ} \mathrm{C}$ until use [22].

\section{Ficus Bengalensis Latex Collection}

Latex was collected locally in early morning 7:00 to 8:00 am, as the flow of latex is low during the day. Collection was done by making 1-2 mm deep vertical incisions on the skin [22]. Latex was extracted by maceration process (48h) in methyl alcohol after defatted with petroleum ether at (72h) at room temperature. The extracted was dried by rotatory evaporator under reduced pressure [23]. The dried latex was triturated using a mortar and pestle. It was stored at $4-8^{0} \mathrm{C}$ until use.

\section{Phytochemical studies}

Phytochemical analysis was carried out on Carica Papaya Latex and Ficus Bengalensis Latex for the detection of various phytochemicals by following standard methods described in practical pharmacognosy by Trease and Evans.

\section{Phytochemical Screening}

Phytochemicals are chemical compounds that occur naturally in plants. The term is generally used to refer to those chemicals that may affect health, but are not established as essential nutrients. The presence of tannins, alkaloids, flavonoids, general test for glycosides (reducing sugars), anthraquinones, sterols and saponins were tested by simple qualitative methods (Trease and Evans, 1989)[24].

\section{Animals}

Albino rats of either sex (Wister strain) weighing 150-200g and female albino mice weighing 20-25g were used in this study. Animals were used from animal house of Sanjay College of Pharmacy, Mathura, U.P.

The animals were acclimatized for ten days under laboratory conditions. They were housed in polypropylene cages and maintained at $27^{\circ} \mathrm{C} \pm 2{ }^{\circ} \mathrm{C}$, relative humidity $65 \pm 10 \%$ under 12 hours light/ dark cycle. The animals were fed with rodent pellet diet (Gold Mohur Lipton India Ltd.) and water ad libitum.

Ethical clearance for performing the experiments on animals was obtained from the Institutional Animal Ethics Committee (IAEC) and registration number 1334/a/10/CPCSEA of Sanjay College of Pharmacy, Mathura, Uttar Pradesh. 


\section{Toxicity study - Determination of acute toxicity $\mathbf{L D}_{50}$}

The acute toxity for Carica Papaya Latex and Ficus Bengalensis latex were determined in female albino mice. The animals were fasted overnight prior to the experiment, fixed dose method of OECD guideline No. 420; (Annexure $2 \mathrm{~d}$ )of CPCSEA was adopted for this purpose. Group of three mice were taken for each test dose and $1 / 10^{\text {th }}$ of $\mathrm{LD}_{50}$ cut off value of test latex selected as screening dose for Hepatoprotective activity [25].

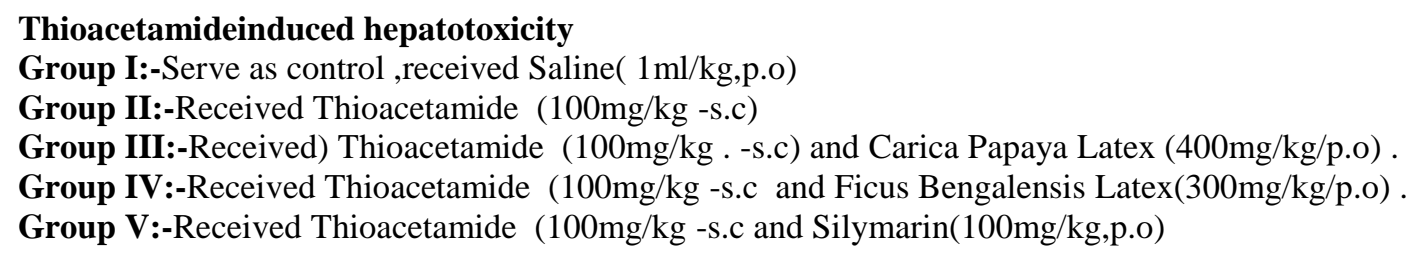

Animals were divided into 5 groups of six animals in each.

Group -I serve as a normal control received Saline $1 \mathrm{ml} / \mathrm{Kg}$ for 10 days. Group -II were administered a single subcutaneous injection of thioacetamide $(100 \mathrm{mg} / \mathrm{Kg}$. sc) as a $2 \% \mathrm{w} / \mathrm{v}$ solution in distilled water. Group -III, IV and V were treated orally with Caraca Papaya Latex (dose $400 \mathrm{mg} / \mathrm{Kg}$.), Ficus Bengalensis Latex (dose 300mg/Kg.) and Silymarin (dose $100 \mathrm{mg} / \mathrm{Kg}$.) once daily for 10 days followed by single subcutaneous injection of Thioacetamide. 24 hours after the Toxin administration, the animals of each group were anaesthetized, the blood were collected directly from the heart. The blood samples were allowed to clot for 20-30 minutes. Serum was separated by centrifugation at $37^{\circ} \mathrm{C}$. Serum was used for estimation of various biochemical parameters such as SGOT, SGPT Bilirubin, ALP and total protein through the auto analyzer for the study of the toxic effect of thioacetamide.

\section{Biochemical Studies}

Estimation of SGPT on blood serum was carried out using AGD Clinipak from AGD Biomedicals Pvt. Ltd. Mumbai.

Estimation of Alkaline Phosphate, Total Protein, SGOT on blood serum was carried out using Diagnostic test kit from Beacon Diagnostic Pvt. Ltd., NAVSARI.

Estimation of Bilirubin on blood serum was carried out using diagnostic kit from SIEMENS Ltd., Vadodara, Gujrat.

\section{Histological studies}

The Liver were isolated from the animals and washed with normal Saline. The liver was fixed in Formalin diluted to $10 \%$ with normal Saline then processed further for histological studies. The results were analyzed by student t-test.

\section{Statistical analysis}

All the values are expressed as mean \pm S.D. result were analyzed statistically by analysis of variance (ANOVA) followed by student $\mathrm{T}$-Test was used for determining significance.

\section{Result And Discussion:-}

The result of present study reveals that level of parameters like SGPT, SGOT, Bilirubin, and ALP were found to be elevated and decrease total protein in Thioacetamide treated group (dose $100 \mathrm{mg} / \mathrm{kg} \mathrm{b.w.)} \mathrm{whereas} \mathrm{treatment} \mathrm{along}$ with Carica Papaya Latex (dose 400mg/kg b.w.) and Thioacetamide (dose $100 \mathrm{mg} / \mathrm{kg}$ b.w.) group shows significant reduction in above said parameter SGPT (180.7 \pm 14.80$)$, SGOT(218.40 \pm 12.4$)$, Bilirubin(2.32 \pm 12.40$)$, and $\operatorname{ALP}(124.8 \pm 7.2)$ and increased total protein $(6.56 \pm 0.34)$ compare to Thioacetamide treated group.

Thioacetamide (dose $100 \mathrm{mg} / \mathrm{kg}$ b.w.) and Ficus Bengalensis Latex treated Group at dose $300 \mathrm{mg} / \mathrm{kg}$ b.w. were found decrease in Serum Level SGPT (186.3 \pm 10.70$)$, SGOT(227.60 \pm 14.8$)$, Bilirubin(2.68 \pm 0.05$)$, and $\operatorname{ALP}(132.6 \pm 8.40)$ and increase total protein $(6.12 \pm 0.11)$ compare to Thioacetamide treated group SGPT (256.4 \pm 12.30$)$, SGOT(338.70 \pm 18.2$)$, Bilirubin(3.88 \pm 0.04$)$, ALP(182.4 \pm 5.20$)$ and total protein $(5.43 \pm 0.025)$. 
Table1:-Effect OfCarica Papaya Latex \&Ficus Bengalensis Latex In Thioacetamide Induced Hepatotoxicity In Albino Rats

\begin{tabular}{|c|c|c|c|c|c|c|}
\hline S.No. & Groups & SGPT(1u/L) & SGOT(1u/L) & Bilirubin(mg/dL) & ALP & T. Protein \\
\hline 1. & Control & $52.36 \pm 2.18$ & $78.32 \pm 3.12$ & $0.96 \pm 0.04$ & $104.5 \pm 6.70$ & $7.78 \pm 0.065$ \\
\hline 2. & $\begin{array}{c}\text { Thioacetamide } \\
\text { treated(100mg/Kg) S.C. }\end{array}$ & $256.4 \pm 12.3$ & $338.7 \pm 18.2$ & $3.88 \pm 0.04$ & $182.4 \pm 5.20$ & $5.43 \pm 0.025$ \\
\hline 3. & $\begin{array}{c}\text { Thioacetamide+ Carica } \\
\text { Papaya Latex }\end{array}$ & $180.7 \pm 14.80^{*}$ & $218.4 \pm 12.4^{*}$ & $2.32 \pm 12.40^{*}$ & $124.8 \pm 7.2^{*}$ & $6.56 \pm 0.34$ \\
\hline 4. & $\begin{array}{c}\text { Thioacetamide+ Ficus } \\
\text { Bengalensis Latex }\end{array}$ & $186.3 \pm 10.70^{*}$ & $227.6 \pm 14.8$ & $2.68 \pm 0.05^{*}$ & $132.6 \pm 8.40$ & $6.12 \pm 0.11$ \\
\hline 5. & $\begin{array}{c}\text { Thioacetamide+ } \\
\text { Silymarin(100mg/Kg) }\end{array}$ & $78.16 \pm 1.40^{* *}$ & $94.86 \pm 2.58^{* *}$ & $1.24 \pm 0.02^{* *}$ & $108.8 \pm 4.40$ & $7.78 \pm 0.43$ \\
\hline
\end{tabular}

All values are expressed in mean $\pm \mathrm{SD} ; \mathrm{n}=6$ Control vs $* \mathrm{P}<0.05, * * \mathrm{P}<0.001$

\section{Histology:-}

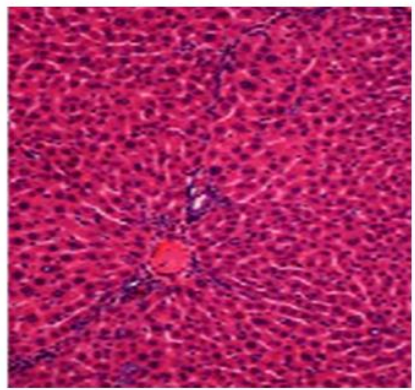

Figure 1:-Control Group

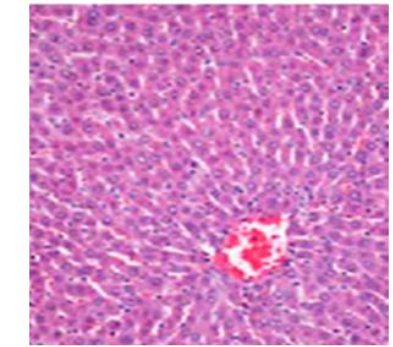

Figure 2:-Thioacetamide Treated Group

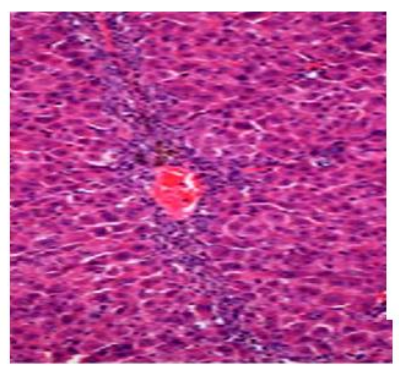

Figure 3:-Thioacetamide and Carica Papaya Latex treated group

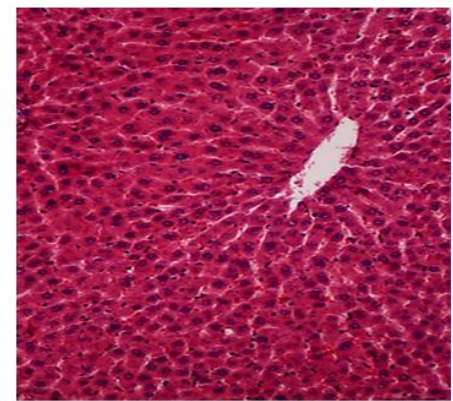

Figure 4:-Thioacetamide and Ficus Bengalensis Latex treated group

The result was shown in Table No.1.represents that Carica Papaya Latex was better reduction in Serum Parameters compare to Ficus Bengalensis Latex.

Phytochemical studies found that both plant carica papaya latex and ficusbengalenesis latex contains flavonoid, carbohydrate, tannins, saponins alkaloid, glycoside, protein

We found that Morphological observations showed an increase the size and enlargement of the liver in Thioacetamide treated group. These changes were reversed by treatment with Silymarin $(100 \mathrm{mg} / \mathrm{kg}$ b.w.), Carica Papaya Latex(400mg/kg b.w.) and Ficus Bengalensis Latex (300mg/kg b.w.).

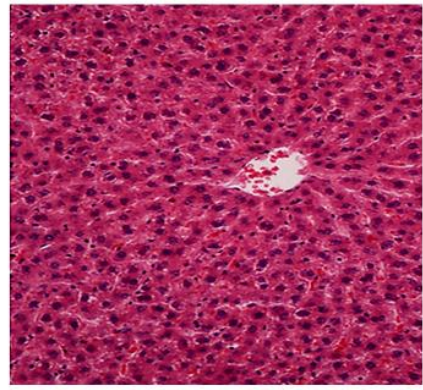

Histological studies showed that Thioacetamide produced extensive vascular degenerative changes and centrilobular necrosis and Hepatocytes. It was shown in figure no. 1 to 5 . 
Administration of Thioacetamide treated group at the dose of $100-300 \mathrm{mg} / \mathrm{kg}$ by s.c. route results in the Hepatic damage in animals. Thioacetamide is a Hepatotoxic that is metabolized by CYP 450 enzymes present in liver microsomes and is converted to a toxic reactive intermediate called Thioacetamide (s-oxide) due to oxidation process. Thioacetamide $s$-oxide induced oxidative stress in the Hepatic cells. It interferes with the movement of RNA from the nucleus to the cytoplasm which may cause membrane injury. It reduce the number of viable Hepatocytes as well as rate of oxygen consumption and also decrease the volume of bile and its content. In the present study groups treated with Thioacetamide100 $\mathrm{mg} / \mathrm{kg}$ [26].

We found that the treatment with both latex prevented elevation of serum parameter like SGPT, SGOT ,Bilirubin , ALT, and decreased total protein due to Thioacetamide challenge models.

Treatment with both latex found that it improved the liver anatomy / hepatic anatomy with normalization of histopathological observation observe after Thioacetamide induced hepatotoxicity.

\section{Conclusion:-}

It is thus concluded that both plant Carica Papaya Latex and Ficus Bengalenesis Latex posseses a hepatoprotective activity against thioacetamide induced hepatotoxicity in rats as evidenced by reduction in serum parameter like SGPT, SGOT, Bilirubin, ALT, and elevation of total protein etc. Whereas Carica Papaya latex was found to be more effective compared to Ficus Bengalenesis Latex.

A finding from the hepatoprotective study indicates that both latex were showed significantly reduced the elevated serum parameter and enhanced the decreased level of total protein induce by hepatotoxin in rats .

\section{References:-}

1. Harsh Mohan, $5^{\text {th }}$ Edition, Text book of Pathology, Jaypee brothers, Daryaganj, New Delhi, page no. 608-609.

2. RajibAhsan, Km Monirul Islam (2009), Hepatoprotective activity of Methanol extract of some medicinal plants against Carbon Tetra Chloride induced hepatotoxicity in Albino rats, Global journal of Pharmacology, 3(3): pp. 116-122.

3. MallikarjunaRaoTalluri, RajanandaswamyTadi (2016), Thioacetamide induced acute liver toxicity in rats treated with Balanitesroxburghii extracts, Journal of acute disease 5(5),pp. 413-418.

4. Sharma A., K.K. Chakraborty and S.S. Handa (1991), Anti-hepatotoxic activity of some Indian herbal formulations as compared to Silymarin, Fitoterapia, 62: pp.229-235.

5. Subramonium, A. and P. Pushpangadan (1999), Development of phytomedicines for liver disease. Indian Journal of Pharmacology, 31: pp. 166-175.

6. Suk KT, Kim MY, Baik SK (2014), Alcoholic liver disease treatment, World J. Gastroenterol, 20(36) pp. 12934-44.

7. Girish C. Pradhan, SC (2012),Indian herbal medicines in the treatment of Liver disease: problems and promises, FundamClin Pharmacology, 26(2), pp. 180-189.

8. Wachtel - Galor S., Benzie IFF (2011), Herbal medicine: Biomolecular and clinical aspects, $2^{\text {nd }}$ Edition, Boca Raton: CRC Press.

9. Phool Chandra, NeetuSachan (2013), Acute \&Subchronic toxicity studies and Pharmacological evaluation of FicusBengalesis on scopolamine induced memory impairment in experimental animals, Indian Journal of drugs, 1(1),pp. 6-16.

10. Mukherjee, P.K. Saha, K. Murugesan, T. Mandal (1998), screening of antidiarrhoeal properties of some plant extracts of a specific region of West Bengal, Indian Journal of Ethanopharmacology, 60,pp.85-89.

11. Husain, A. Virmani, O.P. Popli, S. P. Mishra (1992), Dictionary of Indian Medicinal Plants CIMAP, Lucknow India.

12. Achrekar,S. Kaklaji, G.S. Pote (1991), Hypoglycemic activity of Eugenia Jamolana and Ficus Bengalensis: Mechanism of Action. In VIVO, (5) pp. 143-147.

13. Taur, D.J. Nirmal, S.A. Patil (2007), Anti-stress and Anti-allergic effects of Ficus Bengalensis bark in asthma. Natural Product Research., (21) pp. 1266-1270.

14. Daniel RS,DeviKS,Augusti K.T.,(2003),Indian journal of experimental biology,41(4):pp.296-303.

15. Shukla R., Anand K., Prabhu K.N. (1995), Indian journal Clin. Biochem., (10): pp. 14-18.

16. A AAdeneye, JA Olagunju, (2009), Preliminary hypoglycemic and hypolipidamic activities of the aqueous seed extract of carica Papaya Linn in Wistar rats, Biology and Medicine, vol 1 (1), : 1-10.

17. Duke JA (1984), Border Line Herbs. Boca Raton: CRC Press. 
18. Brocklehurst K, Salih E, McKee R., (1985), Fresh non-fruit latex of carica papaya contains papain, multiple form of chymopapain A and Papaya proteinase omega, Biochemical Journal, 228(2): pp.525-527.

19. Tona L, kambu K, Ngimbi N. (1998), Antimoebic medicinal plants, Journal of Ethanopharmacology, 61(1), pp. 57-65.

20. Odula T, Adeniyi (2007), Toxicity studies on an unripe Carica Papaya aqueous extract: Biochemical and haematological effects in Wister Albino rats, Journal of Medicinal plants research Vol.1 (1), pp. 001-004.

21. Md. ZaforSadeque and ZinnatAra Begum (2010), Protective effect of dried fruits of Carica Papaya on Hepatotoxicity in rats, A Journal of Bangladesh Pharmacological Society, (5) : 48-50.

22. ShilaGurung, Natasha Skalko- Basnet (2009), Wound healing properties of Carica Papaya Latex: In vivo evaluation in mce burn model, Journal of Ethanopharmacology, 121, pp. 338-341.

23. Yogesh C Yadav, (2015), Hepatoprotective effect of Ficusreligiosa latex on cisplatin induced liver injury in Wister rats, RevistaBrasileira De Farmacognosia, pp. 278-283.

24. Trease, G.E. and Evans, W.C. (1989), Pharmacognosy. 11th Edition, BailliereTindall, London, 45-50.

25. Mrs. PremaVeeraraghavan, Expert consultant, CPCSEA, OECD guideline Nol. 420.

26. Anbarasu C, Rajkapoor B, John Giridharan (2012), Protective effect of Pisonia aculeate on thioacetamide induced hepatotoxicity in rats, Asian Pacific Journal of Tropical Biomedicine, 2(7): pp. 511-515. 